Paweł Popieliński

\title{
WPROWADZANIE PODWÓJNEGO \\ NAZEWNICTWA NA TABLICACH MIEJSCOWOŚCI I URZĘDÓW \\ ORAZ JĘZYKA POMOCNICZEGO \\ W GMINACH NA GÓRNYM ŚLĄSKU \\ A ICH SPOŁECZNE POSTRZEGANIE
}

Proces demokratycznych przemian, zapoczątkowany w 1989 roku, przyniósł zmianę polityki państwa wobec mniejszości narodowych i etnicznych. Państwo polskie uznawało potrzebę równouprawnienia mniejszości i zachowania ich tożsamości narodowej przez przyznanie im praw kulturalnych i oświatowych oraz wsparcie finansowe. W III RP mniejszości narodowe i etniczne mają zagwarantowaną ochronę w Konstytucji RP oraz nadane prawa w ustawach dotyczących edukacji, radia i telewizji, ordynacji wyborczej do Sejmu. Poza tym polski system prawny gwarantuje szereg innych praw, które są zgodne ze standardami międzynarodowymi ${ }^{1}$. Jednak do 2005 roku $\mathrm{w}$ prawie polskim nie było uregulowań dotyczących używania języków ojczystych mniejszości przed urzędami i stosowania podwójnego nazewnictwa topograficznego miast i ulic oraz urzędów publicznych. Od tego momentu istnieją także uregulowania dotyczące tych

1 S. Łodziński, Wyrównanie czy uprzywilejowanie? Spory dotyczace projektu ustawy o ochronie mniejszości narodowych (1989-2005), Biuro Studiów i Ekspertyz, Warszawa 2005, s. 1. 
kwestii ${ }^{2}$. Ustawa ta powstała dzięki Sejmowej Komisji Mniejszości Narodowych i Etnicznych.

Prace nad projektem Ustawy o mniejszościach narodowych $i$ etnicznych oraz o jezyku regionalnym (dalej: Ustawa) trwały od 1990 roku. Najgorętszymi jej zwolennikami byli przede wszystkim przedstawiciele mniejszości niemieckiej. W 1998 roku stworzono projekt, który zawierał odniesienia do wszystkich zasad zawartych w Konwencji ramowej o ochronie mniejszości narodowych. Obejmował katalog praw przysługujących mniejszościom narodowym, zakaz dyskryminacji z powodów narodowych lub etnicznych oraz zakaz asymilacji. Na terenach zamieszkałych tradycyjnie lub w znacznej liczbie przez osoby należące do mniejszości narodowych projekt przewidywał możliwość traktowania języków mniejszości jako języków pomocniczych. Uwzględniał możliwość umieszczania w językach mniejszości nazw miejscowości, organów władzy oraz ulic. Gwarantował także prawo urzędowego zapisywania imion i nazwisk zgodnie z zasadami języka ojczystego. Jednak prace nad projektem trwały nadal. Po licznych dyskusjach nad projektem i naniesieniu wielu poprawek 11 stycznia 2003 roku Sejmowa Komisja Mniejszości Narodowych i Etnicznych IV kadencji skierowała do laski marszałkowskiej, jako inicjatywę własną projekt Ustawy w wersji z września 1998 roku. Po wprowadzeniu następnych poprawek i gorącej debacie $\mathrm{w}$ parlamencie przyjęto Ustawe o mniejszościach narodowych $i$ etnicznych oraz o jezyku regionalnym ${ }^{3}$. W sumie prace nad tą ustawą trwały 15 lat; ich ukoronowaniem było podpisanie ustawy 24 stycznia 2005 roku przez Prezydenta Aleksandra Kwaśniewskiego.

Ustawa weszła w życie 1 maja 2005 roku. Uregulowała ona nie tylko sprawy związane z zachowaniem i rozwojem tożsamości kulturowej mniejszości narodowych i etnicznych w Polsce, ale także problem dwujęzyczności - języka pomocniczego oraz dwujęzycznych nazw. Umożliwiła mniejszościom zamieszkującym Polskę wyrażanie i akcentowanie swojej obecności, m.in. przez umieszczenie na tablicach obok

2 I. Niedojadło (oprac. i red.), Informator. Używanie języka mniejszości narodowych jako pomocniczego języka urzędowego w wybranych krajach europejskich, Dom Współpracy Polsko-Niemieckiej, Gliwice - Opole 2003, s. 4.

3 Ustawa o mniejszościach narodowych i etnicznych oraz o języku regionalnym, Dz. U. 2005, nr 17, poz. 141. 
urzędowych nazw miejscowości i obiektów fizjograficznych także nazw w języku mniejszości ${ }^{4}$. Wśród wielu posłów (którzy spowalniali prace nad ustawą) i znacznej części społeczeństwa większościowego największe obawy związane z uchwaleniem ustawy dotyczyły używania podwójnych nazw miejscowości i używania w urzędach języków mniejszości jako języków pomocniczych. Kwestie pielęgnowania kultury i korzystania z edukacji budziły znacznie mniejsze obiekcje i nie powodowały wątpliwości ${ }^{5}$.

Zgodnie z Ustawa osoby należące do mniejszości w Polsce mają prawo powrotu do zapisu swoich imion i nazwisk (dotyczy to przede wszystkim członków mniejszości niemieckiej) w swoim ojczystym języku (art. 7), swobodnego posługiwania się nim w życiu prywatnym i publicznym (art. 8), używania swego języka jako pomocniczego w mowie i piśmie w gminach, w których dana mniejszość według spisu powszechnego przeprowadzonego w 2002 roku (oraz w 2011 roku) stanowi co najmniej $20 \%$ mieszkańców lub po konsultacjach społecznych (art. 9-11). W takich gminach można używać tablic z dwujęzycznymi nazwami miejscowości, urzędów, ulic itd. Nazwy miejscowości i obiektów fizjograficznych w językach mniejszości mogą być wprowadzone na terenie całej gminy lub tylko jej części. Nazwy te nie mogą pochodzić z czasów III Rzeszy, nie mogą też być nadawane przez ZSRR. Nie mogą być stosowane samodzielnie i muszą zawsze wystąpić po oficjalnej nazwie w języku polskim. O zasadach wprowadzenia w życie ustawy musi zadecydować rada danej gminy.

Dodatkowa nazwa miejscowości lub obiektu fizjograficznego w języku mniejszości może być ustalona na wniosek rady gminy, jeżeli liczba mieszkańców gminy należących do danej mniejszości jest nie mniejsza niż 20\% ogółu jej mieszkańców lub za ustaleniem dodatkowej nazwy miejscowości w języku mniejszości opowiedziało się po konsultacjach społecznych ponad 50\% mieszkańców tej miejscowości biorących w nich udział. Następnie wniosek rady gminy musi uzyskać pozytyw-

4 M. Choroś, Dwujęzyczne tablice z nazwami miejscowości na Opolszczyźnie: Przejaw w demokracji czy źródło nowych konfliktów?, „Przegląd Zachodni” 2012, nr 1, s. 127.

5 D. Rzemieniewski, Ustawa wzmocniła wszystkie mniejszości, w: K. Ogiolda (red.), Rozmowy na 10-lecie Ustawy o mniejszościach narodowych i etnicznych, Dom Współpracy Polsko-Niemieckiej, Opole 2015, s. 211. 
ną opinię Komisji Miejscowości i Obiektów Fizjograficznych. Zgodnie $\mathrm{z}$ art. 13 rada gminy przedstawia wniosek o ustalenie dodatkowej nazwy miejscowości lub obiektu fizjograficznego w języku mniejszości na wniosek mieszkańców gminy należących do mniejszości lub z inicjatywy własnej. Wniosek przedstawiany jest ministrowi właściwemu ds. wyznań religijnych oraz mniejszości narodowych i etnicznych za pośrednictwem wojewody. Ustawa określa procedurę związaną z wpisaniem gminy do Urzędowego Rejestru Gmin, na których obszarze używane sa nazwy w języku mniejszości (dalej: Urzędowy Rejestr Gmin).

Dodatkowe nazwy mogą być stosowane jedynie na obszarze gmin wpisanych do Urzędowego Rejestru Gmin prowadzonego obecnie, od grudnia 2015 roku, przez Ministra Spraw Wewnętrznych i Administracji (w okresie od listopada 2011 do grudnia 2015 roku był to Minister Administracji i Cyfryzacji, a wcześniej do listopada 2011 roku był to Minister Spraw Wewnętrznych i Administracji). Minister wpisuje nazwy miejscowości do rejestru na wniosek rady gminy po zasięgnięciu opinii, odnośnie do każdej z proponowanych nazw, Komisji Nazw Miejscowości i Obiektów Fizjograficznych, w której skład wchodzą m.in. specjaliści z zakresu językoznawstwa, historii, geografii i kartografii ${ }^{6}$. Od 2006 roku lista gmin, w tym przede wszystkim miejscowości, które są wpisane do Urzędowego Rejestru Gmin, stopniowo wzrasta.

Wygląd tablic informacyjnych oraz krój liter nazwy polskiej i dodatkowej reguluje Ustawa oraz rozporządzenie Ministra Infrastruktury z 10 sierpnia 2005 roku$^{7}$. Wielkość liter ma być taka sama dla obu nazw - w języku polskim i danej mniejszości. Obie nazwy powinny być umieszczane na tej samej tablicy, powinny być wyśrodkowane, z tym że dodatkowa nazwa w języku mniejszości powinna znajdować się pod nazwą w języku polskim8. Tym samym obie nazwy uzyskują charakter

\footnotetext{
6 Ustawa o mniejszościach....

7 Rozporzadzenie $w$ sprawie umieszczania na znakach $i$ tablicach dodatkowych nazw w językach mniejszości narodowych i etnicznych i języku regionalnym, Dz. U. 2005, nr 157, poz. 1320.

8 Z tego powodu w 2009 roku musiały zostać wymienione na koszt gminy tablice kierunkowe (drogowskazy) z dodatkowymi nazwami niemieckimi w gminie Chrząstowice (pierwotnie na tablicach obie nazwy - polska i niemiecka - były wyrównane do lewej strony).
} 
urzędowy. Mimo jednoznacznych regulacji niektóre gminy, zwłaszcza na początku procesu wprowadzania dodatkowych nazw, umieściły nazwy na dwóch odrębnych tablicach - miało to miejsce m.in. w Łubowicach i gminie Cisek.

Według wyników Narodowego Spisu Powszechnego z 2002 roku w Polsce 51 gmin spełniało kryteria wpisu do Urzędowego Rejestru Gmin, tj. posiadało co najmniej 20\% mieszkańców, którzy deklarowali przynależność do mniejszości narodowej i etnicznej. Spośród 51 gmin spełniających kryteria wspomnianego wpisu do rejestru, w 27 gminach w województwie opolskim i jednej w województwie śląskim można było wprowadzić podwójne nazewnictwo - poza językiem urzędowym można było wprowadzić je także w języku niemieckim. Procedury wprowadzania ustawy w życie zazwyczaj trwają około roku. Jednak należy zaznaczyć, że wpis do wspomnianego rejestru nie oznacza od razu możliwości postawienia tablic z podwójnymi nazwami miejscowości. Część gmin spełniających warunki ustawy z różnych względów wstrzymywała się z wprowadzeniem podwójnego nazewnictwa na swoim terenie - nie mogły lub też nie chciały tego uczynić.

Zgodnie $\mathrm{z}$ art. 15 ustawy o mniejszościach koszty związane z wprowadzeniem dodatkowych nazw ponosi budżet gminy, z wyjątkiem kosztów wymiany tablic informacyjnych, wynikających z ustalenia dodatkowej nazwy miejscowości lub obiektu fizjograficznego w języku mniejszości, które to ponosi budżet państwa. W ten sposób, zgodnie z intencją ustawodawcy, koszt wprowadzania dodatkowych nazw został podzielony pomiędzy budżet państwa i samorząd.

Pierwszą gminą wpisaną do Urzędowego Rejestru Gmin została gmina Radłów (pow. oleski, woj. opolskie), w której od 22 grudnia 2006 roku istnieje 11 dwujęzycznych, polsko-niemieckich, nazw wsi i osad (niecały rok później wprowadzono jeszcze jedną nazwę miejscowości). Gmina ta była także pierwsza, którą wpisano do Urzędowego Rejestru Gmin, z prawem do używania języka niemieckiego jako pomocniczego. Warto w tym miejscu zaznaczyć, że ustawienie tych dwujęzycznych tablic miejscowości nastąpiło dopiero w połowie września 2008 roku, powodem tego był m.in. problem związany z pisownią jednej miejscowości oraz kwestie proceduralne wynikające $\mathrm{z}$ podpisania umowy 
na sfinansowanie postawienia tablic i ogłoszenia przetargu publicznego.

11 kwietnia 2008 roku w gminie Rudnik (pow. raciborski, woj. śląskie) wprowadzono jedną niemiecką nazwę dla wsi Łubowice/Lubowitz. Rudnik był pierwszą gminą na Górnym Śląsku (a zarazem w Polsce), w której ustawiono tablicę z dodatkową nazwą miejscowości w języku niemieckim. Dokonano tego, mimo że mniejszość niemiecka stanowiła poniżej 20\% mieszkańców gminy (13,4\% według Spisu Powszechnego z 2002 roku). Jednak stało się to dzięki konsultacjom społecznym oraz z racji znaczenia miejscowości Łubowice dla Niemców ${ }^{9}$. Uroczystość odsłonięcia tablic odbyła się 4 września 2008 roku ${ }^{10}$. Także we wrześniu 2008 roku wprowadzono pierwszą tablicę z dodatkową nazwą w języku niemieckim w województwie opolskim w gminie Cisek. Pierwszym miastem w Polsce $\mathrm{z}$ dodatkową nazwą $\mathrm{w}$ języku niemieckim była Leśnica/Leschnitz. Dotychczas jednak żadne miasto powiatowe na Górnym Śląsku nie uzyskało dodatkowej nazwy w języku niemieckim, chociaż próg 20\% osób należących do mniejszości niemieckiej według danych spisu powszechnego z 2002 roku spełniło Olesno w województwie opolskim. Na marginesie warto wspomnieć, że pierwsze dwujęzyczne nazwy miejscowości w Polsce pojawiły się w języku kaszubskim w gminie Stężyca na Kaszubach w lipcu 2008 roku.

Ogólnie rzecz biorąc, w 2008 roku do rejestru zostało wpisanych 13 gmin z uprawnieniami do dodatkowych nazw w języku niemieckim. Gmina Radłów stała się przykładem dla innych gmin starających się o wpis do Urzędowego Rejestru Gmin, dzięki któremu mogły wprowadzić dodatkowe nazwy miejscowości. Dla środowisk mniejszości narodowych i etnicznych w Polsce to swoiste urzędowe przetarcie szlaku było ważne, ponieważ odważyły się do zastosowania w swojej gminie wymaganej ustawowo procedury.

9 Jest ona miejscem urodzin jednego z najwybitniejszych niemieckich, górnośląskich poetów epoki romantyzmu Josefa von Eichendorffa (1788-1857). Z tego względu Łubowice odwiedza wielu Niemców oraz działa tam także Górnośląskie Centrum Kultury i Spotkań, które nosi jego imię.

${ }_{10}$ K. Lassak, Relacja z odsłonięcia dwujęzycznych tablic w Eubowicach, źródło: http:// www.raciborz.com.pl/art10049.html (dostęp: 24 stycznia 2015). 
W połowie czerwca 2009 roku ustalono dodatkowe nazwy w języku mniejszości narodowej dla 314 miejscowości i ich części (dla 6 miast, 233 wsi, 45 części wsi, 14 przysiółków, 5 osad, 6 kolonii i 5 części kolonii) w 21 gminach - 197 nazw niemieckich, 86 nazw kaszubskich, 30 nazw litewskich i jedna nazwa łemkowska ${ }^{11}$. Trzy lata później na mocy omawianej ustawy zostało wprowadzone podwójne nazewnictwo miejscowości w 26 gminach województwa opolskiego (w 229 miejscowościach w języku niemieckim) i 2 województwa śląskiego (w 6 miejscowościach w języku niemieckim) zamieszkanych przez mniejszość niemiecką a także w jednej gminie $\mathrm{z}$ mniejszością białoruską $\mathrm{w}$ jednej gminie z mniejszością litewska, 2 gminach łemkowskich oraz w 11 gminach zamieszkanych przez Kaszubów ${ }^{12}$. Niecały rok później liczba podwójnych nazw miejscowości w języku niemieckim wzrosła do $320^{13}$.

Według stanu z 26 lutego 2014 roku do Urzędowego Rejestru Gmin zostały wpisane 342 miejscowości w języku niemieckim - $26 \mathrm{w}$ gminach województwa opolskiego (330 miejscowości) i 3 w gminach województwa śląskiego (12 miejscowości $)^{14}$. Po ostatnich wpisach do wspomnianego rejestru w październiku 2014 roku (stan na styczeń 2016 roku) liczba gmin $\mathrm{z}$ podwójnymi nazwami $\mathrm{w}$ języku niemieckim wzrosła o dwie gminy opolskie z 16 miejscowościami oraz o jedną miejscowość w województwie śląskim ${ }^{15}$. Dla porównania warto wspomnieć, że dodatkowe kaszubskie nazwy miejscowości w województwie pomorskim istnieją w 786 miejscowościach na terenie 23 gmin. Trzydzieści litewskich nazw miejscowości istnieje $\mathrm{w}$ jednej gminie $\mathrm{w}$ województwie podlaskim. $W$ tym też województwie na terenie jednej gminy jest 27 miejscowości w języku białoruskim. W języku łemkowskim na terenie dwóch gmin województwa małopolskiego znajduje się 9 nazw miejscowości ${ }^{16}$.

11 Lista gmin wpisanych na podstawie art. 10 i 12 ustawy $z$ dnia 6 stycznia 2005 r. ..., źródło: http://mac.bip.gov.pl/rejestry/lista-gmin-wpisanych-na-podstawie-art-12-ustawy-z-dnia-6-stycznia-2005-r.html (dostęp: 16 czerwca 2009).

12 Ibidem (dostęp: 9 sierpnia 2012).

13 Ibidem (dostęp: 20 maja 2013).

14 Ibidem (dostęp: 25 marca 2014).

15 Lista gmin..., http://mc.bip.gov.pl/rejestry/lista-gmin-wpisanych-na-podstawieart-12-ustawy-z-dnia-6-stycznia-2005-r.html (dostęp: 18 stycznia 2016).

${ }^{16}$ Ibidem (dostęp: 25 stycznia 2015). 
W sumie na terenie kraju istnieje 51 gmin, w których są nazwy miejscowości w języku mniejszości lub regionalnym. Należy także dodać, że dotychczas $\mathrm{w}$ żadnej $\mathrm{z}$ tych gmin nie ustalono dodatkowych nazw dla wszystkich miejscowości ani nie ustalono żadnej nazwy dla obiektu fizjograficznego (nizin, gór, jezior, rzek itp.) i formalnie nie wprowadzono dodatkowych nazw ulic i placów (nazwy takie jednak spotykane są w niektórych miejscowościach, zwłaszcza na Kaszubach).

Zgodnie z Ustawa o mniejszościach narodowych i etnicznych oraz o języku regionalnym mniejszości mają prawo do używania swego języka jako pomocniczego przed organami gminy - w gminach, w których dana mniejszość według spisu powszechnego przeprowadzonego w 2002 roku stanowi $20 \%$ mieszkańców, a zarazem zostały wpisane do Urzędowego Rejestru Gmin. Warto dodać, że możliwość używania języka pomocniczego oznacza w praktyce, że osoby należące do mniejszości mają prawo do zwracania się do organów gminy w języku pomocniczym w formie pisemnej lub ustnej, przy czym procedura odwoławcza odbywa się wyłącznie w języku urzędowym. Stosowanie języka mniejszościowego w kontaktach petenta $\mathrm{z}$ urzędem jest oparte na zasadzie języka pomocniczego, co w praktyce oznacza, że nie jest on drugim językiem urzędowym na obszarze jego stosowania. Ponadto trzeba zaznaczyć, że język pomocniczy jest ograniczony jedynie do organów administracji gminnej i nie jest stosowany już $\mathrm{w}$ innych instytucjach administracji publicznej działających na terenie danej gminy.

Urzędowy Rejestr Gmin, w których jest używany język pomocniczy zaczął funkcjonować z chwilą wpisania do niego pierwszej gminy - gminy Radłów w dniu 25 stycznia 2006 roku. Należy zaznaczyć, że pierwsze wnioski o wpisanie do Urzędowego Rejestru Gmin składane przez gminy wymagały uzupełnień i korekt, jednak dzięki nabytym doświadczeniom obecnie większość wniosków jest poprawna, a wpis do omawianego rejestru nie zajmuje więcej niż kilka tygodni.

Według aktualizacji z 17 marca 2014 roku (stan na styczeń 2016 rok) w Urzędowym Rejestrze Gmin w 33 gminach, w których istnieje podwójne nazewnictwo miejscowości, wprowadzono w urzędach język mniejszości lub regionalny jako język pomocniczy. W sumie do rejestru są wpisane 22 gminy z językiem niemieckim, 5 gmin z językiem 
kaszubskim, 5 gmin z językiem białoruskim i jedna gmina $\mathrm{z}$ językiem łemkowskim ${ }^{17}$.

Ustawa daje możliwości (art. 12 ust. 5) instalowania zarówno znaków i tablic z podwójnym nazewnictwem, w tym urzędowych nazw miejscowości, jak i obiektów fizjograficznych i nazw ulic. W większości gmin województwa opolskiego, które uzyskały wpis do Urzędowego Rejestru Gmin, istnieją także dwujęzyczne tablice z nazwami urzędów i instytucji publicznych $\mathrm{w}$ danej miejscowości. Najczęściej są to tablice na budynkach urzędów gmin.

Warto zauważyć, że liczba gmin, w których mniejszość niemiecka stanowi ponad 20\% ludności według Narodowego Spisu Powszechnego z 2011 roku, wynosi 22 gminy, w tym 19 znajduje się w województwie opolskim, a $3 \mathrm{w}$ województwie śląskim. W porównaniu z poprzednim Narodowym Spisem Powszechnym z 2002 roku liczba takich gmin zmniejszyła się w województwie opolskim o 7 (odsetek mniejszości niemieckiej w tych gminach wynosił mniej niż $20 \%$ mieszkańców danej gminy), natomiast w województwie śląskim liczba gmin zwiększyła się o jedną gminę ${ }^{18}$. Podczas ostatniego spisu powszechnego (2011) w Pietrowicach Wielkich odsetek mniejszości niemieckiej wynosił ponad $24 \%$ mieszkańców gminy. Jeszcze nie została ona formalnie wpisana do Urzędowego Rejestru Gmin. Jak można zauważyć, mimo że liczba gmin, gdzie mniejszość niemiecka stanowi ponad 20\% ludności według Narodowego Spisu Powszechnego z 2011 roku, zmniejszyła się, to nie będą one wykreślane z Urzędowego Rejestru Gmin i nadal dwujęzyczne nazwy miejscowości (w urzędach i na tablicach informacyjnych) mają swoją moc prawną - pozostaną na swoim miejscu.

W krajobrazie Górnego Śląska, przede wszystkim województwa opolskiego, widać wiele podwójnych nazw miejscowości - w języku polskim oraz niemieckim i bez większego problemu można zorientować się, gdzie znajdują się większe skupiska mniejszości niemieckiej. W tym regionie istnieje duża zmienność historyczna nazewnictwa miejscowo-

17 Urzędowy Rejestr Gmin, w których jest używany język pomocniczy. Stan ze stycznia 2016: http://mc.bip.gov.pl/rejestry/lista-gmin-wpisanych-na-podstawie-art-12-ustawy-zdnia-6-stycznia-2005-r.html (dostęp: 18 stycznia 2016).

18 T. Kionczyk, Ortschilder. Zweisprachige Ortschilder in der Woiwodschaft Schlesien, „Mitteilungen” 2013, nr 1. 
ści w okresie ostatniego stulecia. Najważniejszą rolę odegrały tutaj przemiany nazw dokonane w latach trzydziestych ubiegłego wieku, kiedy tereny dzisiejszego województwa opolskiego znajdowały się w ramach państwa niemieckiego. Wtedy to toczyła się walka z tzw. polską fasada, tj. zniemczaniem słowiańsko - w znacznym stopniu polsko - brzmiących nazw miejscowości ${ }^{19}$. Natomiast po zakończeniu II wojny światowej i przyłączeniu tego obszaru do Polski odbyła się polonizacja nazw miejscowości - walka z tzw. niemiecką fasadą ${ }^{20}$. Rozpoczęto akcję usuwania wszelkich niemieckich śladów, które wskazywałyby na związki historyczne i kulturowe z Niemcami ${ }^{21}$. Zaczęto likwidować niemieckie ślady z przestrzeni publicznej, $\mathrm{w}$ tym przede wszystkim niemieckie nazwy miejscowości ${ }^{22}$, napisy na pomnikach i obiektach sakralnych. Zakazano posługiwania się językiem niemieckim w miejscach publicznych. Rodzimych mieszkańców o niemieckich czy niemiecko brzmiących imionach i nazwiskach zmuszano do ich polonizowania lub nadawania zupełnie innych, nowych polskich imion i nazwisk, które nie miały nic wspólnego z tymi w języku niemieckim ${ }^{23}$. Działania te stanowiły ważny element polityki unifikacyjnej państwa polskiego wobec ziem zachodnich i północnych. A wprowadzanie nazw polskich w miejsce niemieckich miało pomóc przybywającym na te tereny Polakom utożsamiać się z nowym miejscem zamieszkania ${ }^{24}$. Wśród rodzimych mieszkańców pamięć o tych wydarzeniach jest wciąż żywa. Wzmacniały one

19 Szerzej na ten temat np. K. Fiedor, Walka z nazewnictwem polskim na Ślasku w okresie hitlerowskim 1933-1939, Zakład Narodowy im. Ossolińskich-Wydawnictwo, Wrocław 1966.

20 Zob. B. Linek, "Odniemczanie” województwa ślaskiego w latach 1945-1950 (w świetle materiatów wojewódzkich), Instytut Śląski, Opole 1997.

${ }^{21}$ P. Madajczyk, D. Berlińska, Polska jako państwo narodowe. Historia i pamięć, Instytut Studiów Politycznych PAN, Państwowy Instytut Naukowy - Instytut Śląski, Warszawa - Opole 2008, s. 332.

${ }^{22}$ Nadawano zupełnie nowe lub też odtwarzano stare polskie nazwy miejscowości na podstawie istniejących (np. średniowiecznych) źródeł historycznych czy też sięgano do nazw miejscowości zniesionych przez niemieckie władze nazistowskie w połowie lat trzydziestych XX wieku i je polonizowano.

23 B. Nitschke, Wysiedlenie ludności niemieckiej z Polski w latach 1945-1949, Wydawnictwo Adam Marszałek, Toruń 2001, s. 117-133; B. Linek, „Odniemczanie”... .

${ }^{24}$ J. Bartkowski, Tradycja i polityka. Wptyw tradycji kulturowych polskich regionów na wspótczesne zachowania społeczne i polityczne, Wydawnictwo Akademickie Żak, Warszawa 2003 , s. 183-184. 
wśród tej społeczności podział na „swoich” i „obcych”, przywoływały niemieckie sentymenty i pogłębiały dystansowanie się od polskości.

$\mathrm{Na}$ początku lat dziewięćdziesiątych $\mathrm{XX}$ wieku, kiedy tworzyła się i organizowała mniejszość niemiecka w Polsce, chęć wprowadzenia dwujęzycznych nazw miejscowości nie była wyraźnie artykułowana, choć ludność rodzima o opcji niemieckiej pragnęła zachować i zaakcentować swą odrębność narodową. Oficjalnie po raz pierwszy kwestia podwójnego nazewnictwa pojawiła się w Memoriale Rady Naczelnej Stowarzyszeń Niemieckich w Rzeczypospolitej Polskiej z października 1990 roku $^{25}$. Jednakże w Traktacie o dobrym sąsiedztwie i przyjaznej współpracy z 17 czerwca 1991 roku nie wypracowano wspólnego stanowiska w kwestii wprowadzenia na obszarach zamieszkałych przez mniejszość niemiecką oficjalnych nazw topograficznych w języku niemieckim ${ }^{26}$. Ta sprawa oraz kilka innych nie znalazły się $w$ traktacie i miały zostać uregulowane w przyszłości.

Mimo że kwestia ta nie została oficjalnie uznana, a tym samym brakowało oficjalnej zgody władz polskich, to oznaczenia miejscowości w języku niemieckim funkcjonowały już w przestrzeni publicznej. Używano ich podczas rozmów między sobą w kręgu ludności rodzimej o opcji niemieckiej (mniejszości niemieckiej), audycjach radiowych i telewizyjnych przeznaczonych dla tej społeczności, a także w nagłówkach na papierze firmowym czy pieczęciach kół DFK (lokalnych kół organizacji mniejszości niemieckiej) i na tablicach domów spotkań - lokalnych siedzib mniejszości niemieckiej. Mniejszość niemiecka w niektórych miejscowościach w województwie opolskim nie czekając na rozwiązania prawne zaczęła samowolnie ustawiać tablice $\mathrm{z}$ nazwami w języku niemieckim, które były nadane w latach trzydziestych ubiegłego wie$\mathrm{ku}$. Budziły one negatywne reakcje społeczne i emocjonalne dyskusje w środkach masowego przekazu.

Stosowanie takich nazw wynikało $\mathrm{z}$ tego, że były one w powszechnym użyciu wśród rodzimych mieszkańców tych miejscowości i w za-

${ }_{25}$ M. Lis, Ludność rodzima na Ślasku Opolskim po II wojnie światowej (1945-1993), Państwowy Instytut Naukowy, Instytut Śląski, Opole 1993, s. 198.

${ }_{26}$ W Traktacie między Rzeczypospolitą Polską a Republiką Federalną Niemiec o dobrym sąsiedztwie i przyjaznej współpracy z 17 czerwca 1991 roku, uregulowano m.in. prawa i obowiązki mniejszości niemieckiej w Polsce oraz Polaków w RFN. 
sadzie tylko takie nazwy pamiętali najstarsi mieszkańcy z czasów ich dzieciństwa w okresie III Rzeszy (wcześniejszych w zasadzie nikt nie znał), a ponadto nazwy te figurowały $w$ zachowanych starych niemieckich dokumentach (np. na metrykach urodzenia, świadectwach szkolnych itp.) oraz pamiątkach rodzinnych. Istniały w pamięci zbiorowej tej społeczności, a zarazem brzmiały bardziej niemiecko niż te historyczne i podkreślały niemieckość mieszkańców. Działacze oraz szeregowi członkowie mniejszości niemieckiej byli jednak zgodni, aby nie stosować typowej hitlerowskiej nazwy dla dzisiejszej wsi Szczedrzyk, jakim była nazwa Hitlersee. Należy podkreślić, że w świetle badań przeprowadzonych w latach dziewięćdziesiątych ubiegłego wieku oraz na początku XXI wieku wśród polskiego społeczeństwa istniało przyzwolenie jedynie dla nazw historycznych, które są zakorzenione $\mathrm{w}$ długiej i powikłanej tradycji ziemi śląskiej ${ }^{27}$.

Po wejściu w życie Ustawy w krajobrazie województwa opolskiego od 2008 roku można zauważyć wiele dwujęzycznych nazw miejscowości na tablicach przy wjeździe i wyjeździe z danej miejscowości. Niemieckie nazwy nie pochodzą z okresu III Rzeszy, lecz są nazwami historycznymi.

W rzeczywistości część historycznych nazw miejscowości posiada niemieckie korzenie, są czysto niemieckimi nazwami, przykładowo takie jak: Buhlau/Buława, Charlottenthal/Klekotna, Finkenstein/Brzezie, Friedersdorf/Biedrzychowice, Georgenwerk/Bukowo, Kieferstädtel/Sośnicowice, Lorenzdorf/Wawrzyńcowice, Oderwalde/Dziergowice, Reinschdorf/Reńska Wieś, Rothhaus/Osiny, Stubendorf/Izbicko, Straßenkrug/Biskupskie Drogi, Tempelhof/Niwki, jednak większość nazw ma słowiańskie korzenie, np. takie miejscowości jak Bresnitz/ Brzeźnica, Chronstau/Chrząstowice, Dembio/Dębie, Goslawitz/Gosławice, Krzanowitz/Krzanowice, Konty/Kąty Opolskie, Mokrau/Mokra, Psurow/Psurów, Radlau/Radłów, Schartowitz/Czartowice, Wilkau/Wilków, Wollentschin/Wolęcin.

Jak można zauważyć, znaczna część nazw miejscowości ma słowiański rodowód, lecz zapisane są według niemieckiej transkrypcji (część

${ }_{27}$ M. Wagińska-Marzec, Postawy mieszkańców Opolszczyzny wobec podwójnych nazw miejscowości. „Zeszyty Instytutu Zachodniego” 2003, nr 31, s. 16-17. 
z nich posiada typowo niemiecką końcówkę, np. Radlau). Urzędnicy niemieccy często łamali sobie języki na tych słowiańskich nazwach i nie wiedzieli, jak je zapisać. Przykładem może być miejscowość Chrzumczütz (Chrząszczyce) i wiele innych w regionie (i nie tylko). Można także rzec, że nazwy te mają swoisty gwarowy charakter.

Pierwszym odsłonięciom podwójnych nazw miejscowości (np. w Radłowie/Radlau) nadawano uroczysty charakter. $\mathrm{W}$ obecności przedstawicieli rządów Polski i Republiki Federalnej Niemiec, władz wojewódzkich i władz mniejszości dokonywano uroczystego odsłonięcia tablic symbolicznym przecięciem wstęg w barwach polskich i niemieckich, przy dźwiękach hymnu Unii Europejskiej.

Wprowadzenie podwójnego nazewnictwa oraz języka niemieckiego jako pomocniczego w urzędach na Górnym Śląsku ma świadczyć nie tylko o wielonarodowej historii oraz wielokulturowości tego regionu, ale ma być także potwierdzeniem niemieckiej tożsamości narodowej członków mniejszości niemieckiej, sposobem na zaznaczenie swojej odrębności narodowej w sferze publicznej i podtrzymanie swojej tożsamości kulturowej, ma zaświadczać o jej obecności w społeczności lokalnej, a zarazem jej pozycji w regionie. Ma także stanowić formę symbolicznego zadośćuczynienia dla osób wywodzących się z tej społeczności, która została pozbawiona po II wojnie światowej, w okresie PRL, możliwości publicznego używania języka niemieckiego ${ }^{28}$. Podwójne nazwy na tablicach miejscowości czy na urzędach są przede wszystkim widocznym znakiem w przestrzeni publicznej, zaznaczającym teren zamieszkania mniejszości, są także świadectwem pamięci i szacunku dla korzeni regionu i języka mniejszości oraz służą podtrzymaniu jej tożsamości, są symbolem jej obecności. Wzmacniają także wśród nich przywiązanie do stron rodzinnych (Heimatu) ${ }^{29}$.

Dla ludzi w podeszłym wieku, chociaż sami nie pamiętają starych historycznych nazw miejscowości, wprowadzenie podwójnego nazewnictwa jest ważną kwestią związaną z poczuciem własnej przeszłości.

28 D. Berlińska, Mniejszość niemiecka na Ślasku Opolskim w poszukiwaniu tożsamości, Instytut Śląski, Opole 1999, s. 252-256.

29 Por. Ch. Bergner, Podwójne tablice sa standardem europejskim, w: K. Ogiolda (red.), Rozmowy na 10-lecie Ustawy o mniejszościach narodowych i etnicznych, Dom Współpracy Polsko-Niemieckiej, Opole 2015, s. 26. 
Dla ludzi ze średniego pokolenia jest to rodzaj podkreślenia pewnej podmiotowości, że „my tu jesteśmy”. Natomiast dla ludzi młodych stanowi pewien rodzaj refleksji historycznej. Trzeba podkreślić, że nazwy w języku niemieckim są uważane przez rodzimych mieszkańców o opcji niemieckiej za część ich niemieckiej tożsamości narodowej. Podkreślają poczucie przynależności „lokalnej” tej społeczności - śląskiej tożsamości regionalnej. Pomagają jej odpowiedzieć na podstawowe pytania, skąd pochodzę oraz kim jestem w sensie kulturowo-historycznym. Określają związek i identyfikację rodzimych mieszkańców z miejscem zamieszkania. Stanowią swoisty dokument kultury oraz świadectwo przeszłości regionu.

Należy pamiętać, że dla osób należących do mniejszości narodowych język ojczysty pozostaje jednym z najważniejszych czynników ich tożsamości i nie ma tutaj znaczenia ani stopień jego znajomości (biegłość i kompetencja w posługiwaniu się tym językiem), ani też zakres jego używania w życiu społecznym i publicznym ${ }^{30}$.

Dwujęzyczne nazwy są symbolem, że Polska jest wspólną ojczyzną obywateli różnych narodowości. Państwo polskie poprzez te tablice wspiera mniejszości w ich rozwoju, pokazuje, że mniejszość jest ważną i traktowaną równoprawnie grupą obywateli. Poza tym tablice są elementem polityki Unii Europejskiej wobec mniejszości, realizowanym przez państwo polskie $\mathrm{w}$ ramach tejże Unii ${ }^{31}$. Ważnym argumentem procesu stosowania nazw dwujęzycznych stała się ich "europejskość”, tj. powoływanie się na podobne rozwiązania istniejące w różnych krajach europejskich, w których podwójne nazewnictwo należy do standardów. Obok nazw w językach urzędowych występują także nazwy w językach mniejszości. Rozwiązania dotyczące dwujęzyczności przyjęte w polskiej ustawie opierają się na podobnych rozwiązaniach obowiązujących w innych państwach europejskich. Przede wszystkim takich jak: Niemcy, Austria, Słowenia, Chorwacja, Węgry, Rumunia, Czechy ${ }^{32}$.

30 The Language Rights of Persons Belonging to National Minorities under the Framework Convention, "Thematic Commentary" 2012, nr 3, s. 6-7.

31 Dwujęzyczne nazwy miejscowości, źródło: http://www.tskn.vdg.pl/de/kommentareerklaerungen/463-dwujzyczne-nazwy-miejscowoci?start=3 (dostęp: 25 stycznia 2015).

32 I. Niedojadło (oprac. i red.), Informator..., s. 27-28. 
Zapowiedzi realizacji postanowień Ustawy o mniejszościach narodowych i etnicznych oraz o jezzyku regionalnym, a zwłaszcza możliwości wprowadzenia podwójnych nazw miejscowości, budziły szczególnie na Górnym Śląsku spory niepokój wśród części społeczeństwa polskiego. Oponenci i sceptycy (w tym część posłów ${ }^{33}$ ) byli przekonani, że zapisy ustawy będą dzielić mniejszość niemiecką i większość polską, staną się elementem „obcości” w krajobrazie kulturowym regionu i zostaną wykorzystane do celów politycznych. Przy czym staną się przedmiotem niechęci oraz polaryzacji większości i mniejszości na poziomie lokalnym ${ }^{34}$.

Społeczeństwo województwa opolskiego było w kwestii wprowadzania podwójnego nazewnictwa na ich terenie podzielone. Oponenci podkreślali, że realizacja ustawy będzie traktowana jako przejaw germanizacji województwa, a nie jako wypełnianie europejskich standardów ochrony mniejszości narodowych. Odczytywali ją bardziej w kategoriach ograniczenia roli języka polskiego i suwerenności państwa niż podniesienia statusu grupy niemieckiej. Uznawali, że jest to niepotrzebny wydatek z budżetu państwa lub gminy. Zamiast nich widzieliby raczej odnowione ulice (np. położenie nowego asfaltu lub chodnika) i inne inwestycje służące społeczności lokalnej. Regulacje dotyczące dodatkowych nazw oraz języka pomocniczego zyskały niewielką akceptację badanych zarówno w sondażach opinii publicznej, jak i wśród urzędników lokalnych ${ }^{35}$.

Negatywne reakcje i opinie pojawiły się zwłaszcza po ustawieniu pierwszych tablic. Okazało się, że nazwy w języku niemieckim drażnią i obrażają uczucia części polskiego społeczeństwa, i to nawet te, które mają polski rodowód i nieznacznie różnią się od polskiej (są zapisane zgodnie z niemiecką transkrypcją lub posiadają niemiecką końcówkę). Nazwy te były odbierane (obecnie już w znacznie mniejszym stopniu)

33 Prace nad ustawą trwały 15 lat. Od samego początku wywoływała ona wśród posłów wiele sporów i kontrowersji. Część z nich zastanawiała się, czy ustawa jest potrzebna. $W$ ciągu tych lat zamawiano wiele ekspertyz, zadawano mnóstwo pytań, których celem było m.in. odwlekanie wprowadzenia w życie ustawy.

${ }^{34}$ M. Wagińska-Marzec, Problem nazewnictwa na Ziemiach Zachodnich i Pótnocnych $w$ świetle ustawy o mniejszościach narodowych i etnicznych, w: A. Sakson (red.), Ziemie Zachodnie - Ziemie Zachodnie i Pótnocne 1945-2005. 60 lat w granicach państwa polskiego, Instytut Zachodni, Muzeum Pomorza Środkowego, Poznań - Słupsk 2006, s. 341-342.

35 S. Łodziński, Wyrównanie czy uprzywilejowanie?..., s. 26. 
jako element germanizacji regionu, „obcości” w krajobrazie kulturowym, przez co część mieszkańców mogła lub może się czuć nieswojo, mogła lub może odnieść wrażenie, że jest nie „u siebie”. Dla tych osób niemieckie nazwy naruszały lub naruszają - ich zdaniem - suwerenność terytorialna, jednolitość językową, kulturową i narodową danej miejscowości. Były czy też są one podważeniem obecności Polaków na tych ziemiach, które po II wojnie światowej znalazły się $\mathrm{w}$ granicach państwowości polskiej. Ponadto podkreślanie niemieckiej przeszłości Górnego Śląska, szczególnie na ziemi opolskiej budzi lęk wśród niektórych najbliższych sąsiadów, z którymi członkowie mniejszości niemieckiej dobrze żyją od dziesiątków lat ${ }^{36}$. W tym miejscu warto wspomnieć, że część polskich mieszkańców z miejscowości, w których ustawiono tablice $\mathrm{z}$ podwójnym nazewnictwem, spotyka się z zarzutami ze strony niektórych swoich rodaków z innych miejscowości (z jednolitym polskim nazewnictwem), że dopuścili do usankcjonowania tego faktu. Przez niektórych kwestia ta jest postrzegana wręcz jako rodzaj germanizacji polskich miejscowości, a zarazem zdrada polskości żyjących w nich Polaków.

Rosnące emocje i kontrowersje wokół podwójnego nazewnictwa przyciągaja, a zwłaszcza kilka lat temu przyciągały, uwagę środków masowego przekazu, nie tylko lokalnych gazet, ale także telewizji i czasopism o zasięgu ogólnokrajowym ${ }^{37}$. $Z$ dyskusji toczących się $w$ prasie, telewizji i na forach internetowych niejednokrotnie wyłaniały się postawy ksenofobiczne, niechęć, a nawet wrogość do Niemców, mająca swoje źródło w historii wzajemnych stosunków polsko-niemieckich (zwłaszcza z okresu II wojny światowej) ${ }^{38}$. Tylko nieliczne wypowiedzi podkreślały wagę przyjętych rozwiązań z uwagi na szacunek dla mniejszości niemieckiej, jej śląskiego rodowodu itp. Podwójne nazewnictwo wzbudza niechęć i sprzeciw szczególnie w grupie osób starszych, wychowanych w czasach komunistycznych oraz w środowisku polskich narodowców i skrajnej prawicy. Trzeba zdać sobie sprawę, że wśród części społe-

36 B. Dżon, Kogo bola oczy od niemieckich nazw, „Przegląd” 2008, nr 28, źródło: http://www.przeglad-tygodnik.pl/pl/artykul/kogo-bola-oczy-od-niemieckich-nazw (dostę: 24 stycznia 2015).

37 M. Choroś, Dwujęzyczne tablice..., s. 131.

38 Ibidem, s. 140. 
czeństwa ciągle mamy do czynienia z resentymentami antyniemieckimi, które wynikają z historii, z poczucia obecności dużego sąsiada, który kiedyś był zagrożeniem. Mimo że Polacy mogą być szczególnie wrażliwi na niemieckie nazwy ze względu na przeszłość historyczną to nazwy są dwujęzyczne i nikt nikogo nie zmusza do używania wyłącznie nazw niemieckich. Tak samo jest w przypadku języka niemieckiego jako pomocniczego w urzędach. Ten fakt nie oznacza wcale, że Polacy muszą składać podania lub komunikować się w obcym języku.

Ciekawym zjawiskiem jest to, że wprowadzenie języka niemieckiego jako pomocniczego w urzędach gmin $\mathrm{w}$ województwie opolskim nie rodziło negatywnych reakcji społeczeństwa - polskich mieszkańców. W zasadzie pozostało ono niezauważone - wprowadzenie języka pomocniczego nie było tak nagłośnione w środkach masowego przekazu jak stosowanie podwójnych nazw miejscowości. Może to wynikać z faktu, że posługiwanie się językiem niemieckim w urzędzie gminy jest sprawą bardziej indywidualną niż publiczną. Ponadto z tej możliwości wiele osób nie korzysta. W tej kwestii przeważa pragmatyzm. W zasadzie wszystkie generacje mniejszości niemieckiej posługują się wyśmienicie językiem polskim w mowie i piśmie. Zdecydowana większość dzisiejszych członków mniejszości niemieckiej kończyła polskie szkoły. Często język polski znają dużo lepiej niż niemiecki. Ponadto praktycznie jest im szybciej porozumieć się w języku polskim niż niemieckim - osobiście w urzędzie lub dzwoniąc czy wysyłając do niego maila. Zazwyczaj wnioski lub zapytania telefoniczne $\mathrm{w}$ języku niemieckim kierują do urzędu osoby w podeszłym wieku, ale też osoby, które chcą sprawdzić jak wygląda załatwianie spraw w języku niemieckim lub pochodzą z Górnego Śląska, a mieszkają od wielu lat w Niemczech i łatwiej jest im załatwić urzędowe sprawy w języku niemieckim niż polskim.

Większym problemem stały się próby rozszerzenia dodatkowego nazewnictwa miejscowości w języku niemieckim na dwujęzyczne tablice z nazwami urzędów gmin. Jednak ludzie z czasem przyzwyczaili się do tej ikonografii na budynkach urzędów.

Wprowadzanie dodatkowych nazw w języku mniejszości rozpoczęło się po trzech latach od wejścia Ustawy w życie. Początkowo rady gmin uznały, że jest to temat delikatny i mogący budzić emocje, 
dlatego dopiero po dłuższym okresie zaczęły wprowadzać podwójne nazwy na swoim terenie, poprzedzając je najpierw konsultacjami społecznymi we wszystkich swoich miejscowościach, nawet wtedy, gdy zgodnie z przepisami ustawy nie było to konieczne. Jednak $\mathrm{w}$ ten sposób uczyniły to takie gminy jak np.: Dobrodzień, Cisek, Chrząstowice czy Leśnica (w tych gminach podczas spisu powszechnego z 2002 roku osoby należące do mniejszości niemieckiej stanowiły ponad $20 \%$ ogółu mieszkańców) $)^{39}$.

Konsultacje są jedną z form dialogu społecznego, istotnym elementem pozwalającym ocenić poziom akceptacji wprowadzenia podwójnego nazewnictwa na terenie danej gminy. Ustawa nie określa, jaki odsetek mieszkańców musi uczestniczyć w konsultacjach, jednak ważne jest to, aby opowiedziała się za tym większość uczestniczących. Zazwyczaj bierze $w$ nich udział niewielki odsetek społeczności lokalnej. W niektórych gminach, w których mniejszość niemiecka stanowi poniżej 20\% mieszkańców, sprawa przeprowadzenia konsultacji budzi większe emocje, np. w gminie Krapkowice, Strzelce Opolskie czy Olesno, ponieważ rady gminne, w których kompetencjach leży decyzja o jej przeprowadzeniu, odrzuciły uchwały $\mathrm{w}$ tej sprawie. Wiele emocji wzbudziła decyzja gminnej rady w Ozimku, gdzie po przeprowadzeniu konsultacji w miejscowościach na terenie gminy, odrzuciła ona uchwałę wprowadzającą podwójne nazewnictwo ${ }^{40}$. Negatywna decyzja rady gminy Ozimek spotkała się ze zdecydowanym sprzeciwem przedstawicieli mniejszości niemieckiej, którzy w marcu 2013 roku skierowali skargę do wojewody opolskiego oraz wystosowali list do marszałka Sejmu RP z prośbą o interpretację ustawy o mniejszościach w zakresie konsultacji społecznych przy staraniu się o dodatkowe nazwy miejscowości $\mathrm{w}$ językach mniejszości ${ }^{41}$. Tego typu problemy miała rozwiązać

39 M. Choroś, Ł. Jarczak, Wprowadzanie dwujęzycznych nazw miejscowości na Śląsku Opolskim po 1989, "Studia Śląskie” 2010, t. 69, s. 230; S. Łodziński, "Język niemiecki jako język mniejszości narodowej w lokalnej przestrzeni publicznej. Przykład języka niemieckiego jako pomocniczego oraz dodatkowych niemieckich nazw miejscowości w województwie opolskim", s. 16 (wydruk komputerowy w posiadaniu autora).

40 M. Choroś, Dwujęzyczne tablice..., s. 131.

${ }^{41}$ Jest skarga w sprawie tablic dwujęzycznych w Ozimku, "Nowa Trybuna Opolska”, 6 marca 2013, źródło: http://www.nto.pl/apps/pbcs.dll/article?AID=/20130306/HEIMAT /130309701 (dostęp: 24 stycznia 2015); Zarząd TSKN reaguje na decyzje radnych Ozimka, 
nowelizacja ustawy o mniejszościach narodowych i etnicznych oraz języku regionalnym w 2015 roku, o czym dalej w tekście.

Znacznym wyzwaniem stało się także rozszerzenie dodatkowego nazewnictwa na drogowe tablice kierunkowe oraz stacje kolejowe. Pierwsze takie tablice ustawiono w gminie Chrząstowice. Po spełnieniu wymogów ustawy o postawieniu tablic z dwujęzycznymi nazwami miejscowości rada gminy zdecydowała o umieszczeniu na jej terenie drogowskazów z dodatkowymi nazwami miejscowości. Oddział Generalnej Dyrekcji Dróg Krajowych i Autostrad w Opolu oraz Departament Dróg i Transportu Drogowego ówczesnego Ministerstwa Transportu sprzeciwiały się ustawianiu takich tablic. Argumentowano, że obniżają one czytelność i wartość informacyjną. Jednak po interwencji i wyjaśnieniach Departamentu Wyznań i Mniejszości Narodowych MSWiA została wydana zgoda na postawienie takich tablic. Stanęły one w 2009 roku $^{42}$.

Natomiast próby wprowadzania dodatkowych nazw miejscowości na stacjach kolejowych na terenie gminy Chrząstowice w miejscowościach Suchy Bór, Chrząstowice oraz Dębska Kuźnia spotkały się ze sprzeciwem Zakładu Linii Kolejowych w Opolu. Motywował to wysokimi kosztami związanymi m.in. z koniecznością zmiany rozkładu jazdy i modyfikacji systemów informatycznych. W tym przypadku także interweniował Departament Wyznań i Mniejszości MSWiA,podkreślając przy tym, że ustawa o mniejszościach nie przewiduje umieszczania dodatkowych nazw miejscowości w innych miejscach niż znaki i tablice. Ostatecznie w październiku 2012 roku pojawiły się dodatkowe nazwy na wspomnianych trzech stacjach kolejowych, wywołując negatywne reakcje społeczne podobnie jak w przypadku dwujęzycznych tablic miejscowości ${ }^{43}$.

Kilka miesięcy później, w 2013 roku Polskie Koleje Państwowe (PKP) zdecydowały się na modernizację trasy kolejowej Opole-Częstochowa, w tym również dworców kolejowych w Chrząstowicach, Dębskiej Kuźni oraz Suchym Borze. Przy modernizacji zdemontowano dwujęzyczne tablice, a po zakończeniu prac już ich ponownie nie za-

źródło: http://www.vdg.pl/pl/article/498-zarzad-tskn-reaguje-na-decyzje-radnych-ozimka (dostęp: 24 stycznia 2015).

42 S. Łodziński, Język niemiecki..., s. 19.

43 Ibidem. 
wieszono. Przez wiele miesięcy zgodnie z prawem wójt Chrząstowic zabiegał w PKP oraz w Ministerstwie Administracji i Cyfryzacji (następca MSWiA) o przywrócenie dwujęzycznych tablic na trzech dworcach znajdujących się na terenie gminy. Staraniem wójta dwie z trzech tablic zostały ponownie zamontowane 11 grudnia 2015 roku - w Chrząstowicach i Dębskiej Kuźni. Trzecia tablica dwujęzyczna w Suchym Borze już nie wróciła. Według rejestrów PKP, stacja w tej miejscowości nosi nazwę Suchy Bór Opolski, co nie jest tożsame z polską nazwą miejscowości, tłumaczoną na język niemiecki. Tym samym PKP nie wyraziły zgody na zamontowanie tej tablicy ${ }^{44}$. Wójt gminy nadal stara się o przywrócenie dwujęzycznej tablicy kolejowej na stacji w Suchym Borze. Należy podkreślić, że gmina Chrząstowice jako pierwsza i dotychczas jedyna w Polsce wprowadziła tablice kierunkowe i tablice dwujęzyczne na wspomnianych dworcach kolejowych.

Dotychczas nie zostały złożone wnioski o dodatkowe nazwy ulic i nazw topograficznych („obiektów fizjograficznych”) w języku niemieckim. Przyczyną tego są przede wszystkim koszty wymiany tablic, które pokrywane są z budżetu gminy i dodatkowo go obciążają ${ }^{45}$. Ponadto $\mathrm{w}$ regionie jest niewiele szyldów w języku niemieckim. $\mathrm{W}$ zasadzie nie ma napisów w tym języku na obiektach handlowych, lokalach gastronomicznych, zakładach rzemieślniczych i firmach. To z kolei wynika $\mathrm{z}$ tego, że w regionie nie ma silnej potrzeby nasączenia niemieckimi elementami. Gdzieniegdzie tylko pojawia się napis w języku niemieckim „Herzlich willkommen” (Serdecznie witamy) lub „Zimmer Frei” (wolny pokój), na siedzibach organizacji mniejszości niemieckiej czy niektórych urzędach gmin w województwie opolskim. Dlatego nie można mówić o dominacji niemczyzny $\mathrm{w}$ regionie.

Zwłaszcza w pierwszych latach wprowadzania dwujęzycznych tablic w opolskich wsiach można było zauważyć akty wandalizmu.

${ }_{44}$ Die Zweisprachigenortsschilder kehren auf den Bahnhof in Chronstau und in Dembiohammer zurück, http://www.tskn.vdg.pl/aktualnosci/1159-die-zweisprachigenortsschilderkehren-auf-den-bahnhof-in-chronstau-und-in-dembiohammer-zurueck (dostęp: 5 stycznia 2016).

${ }^{45}$ III Raport dla Sekretarza Generalnego Rady Europy z realizacji przez Rzeczpospolita Polska postanowień Konwencji Ramowej o Ochronie Mniejszości Narodowych, Warszawa 2012, s. 102. 
Głównie miało to miejsce przy głównych drogach z Opola do Katowic - w gminie Izbicko; do Warszawy - w gminach Chrząstowice, Dobrodzień; oraz do Namysłowa - gmina Dobrzeń Wielki.

Mimo że niemieckie nazwy miejscowości na dwujęzycznej tablicy mają $\mathrm{w}$ zdecydowanej większości słowiański rodowód, to na terenie Górnego Śląska, szczególnie na opolskich wsiach, wśród części społeczności budziły one mieszane uczucia. Niektórzy odbierają je jako wyraz podkreślania niemieckości tego regionu, co budzi (choć dziś już rzadko) negatywne emocje, wyrażające się $\mathrm{w}$ incydentach polegających na zamalowywaniu napisów zazwyczaj sprayem (trudno zmywalną farbą lub w inny sposób). Działanie to jest rodzajem manifestacji, że nie akceptuje się tych nazw, ale i wyrazem nietolerancji. Przykładowo kilka dni po ustawieniu tablic w Radłowie zamalowano czerwonym sprayem napis w języku niemieckim, a czarnym w Kolonii Biskupskiej. Podejrzenie padło na radykalnych narodowców z Częstochowy oddalonej od Radłowa ok. $50 \mathrm{~km}$. Wywodzący się stamtąd członkowie Obozu Narodowo-Radykalnego często odwiedzają ziemię opolską. Jednak okazało się, że sprawcami wandalizmu są trzej uczniowie gimnazjum w Radłowie. Z ich zeznań wynikało, że nie zrobili tego z ideologicznych pobudek, lecz był to po prostu chuligański wybryk. Takich przypadków jak ten wydarzyło się dotychczas kilkadziesiąt (jeśli nie więcej), jednak w większości nie można znaleźć sprawców, udowodnić komuś winy.

Zdaniem Danuty Berlińskiej, „w wielu regionach wielokulturowych znajdują się osoby lub grupy - zwykle nieliczne - negatywnie nastawione do symbolicznego manifestowania tej wielokulturowości. Walczą one m.in. - zwykle za pomocą farby - z wielojęzycznymi nazwami miejscowości. Jeśli jednak natychmiast nie przywracamy tablic do ich stanu pierwotnego, oznacza to, że jest społeczne przyzwolenie na takie zachowania. Tablice powinny więc być pokryte specjalną powłoką która umożliwia szybkie i skuteczne zmycie farby"46.

Od co najmniej pięciu lat pojawiają się propozycje nowelizacji ustawy o mniejszościach narodowych i etnicznych. Przedstawiciele mniej-

${ }^{46}$ K. Ogiolda, Dwujęzyczne nazwy miejscowości ustanowiono już w 9 gminach województwa opolskiego, www.nto.pl/apps/pbcs.dll/article?AID=/20090930/HEIMAT (dostęp: 24 stycznia 2015). 
szości narodowych i etnicznych (przede wszystkim Niemcy, Litwini, Białorusini i Kaszubi) uważają że niektóre zapisy ustawy o mniejszościach narodowych i etnicznych należałoby poprawić. Grupa posłów wraz członkami Komisji Wspólnej Rządu i Mniejszości Narodowych i Etnicznych stworzyła nowelizację ustawy, która dotyczyła głównie używania języka mniejszości jako języka pomocniczego nie tylko $\mathrm{w}$ gminie $^{47}$, ale także $\mathrm{w}$ powiecie, w tym możliwości otrzymywania dwujęzycznych dokumentów czy zaświadczeń, oraz umożliwiała mniejszościom narodowym odwołanie się, gdy wniosek w sprawie nadania miejscowościom dwujęzycznych nazw zostaje odrzucony bez uchwały rady gminy.

27 października 2015 roku prezydent Andrzej Duda zawetował nowelizację ustawy o mniejszościach narodowych i etnicznych oraz o języku regionalnym ważną dla nielicznych mniejszości, która uzupełniała dotychczasowe prawne mechanizmy ich funkcjonowania. Najważniejszą zmianą wynikającą z noweli była możliwość używania przed organami powiatu, obok języka urzędowego - języka mniejszości. Wątpliwość prezydenta wzbudziła możliwość używania obok języka urzędowego języka mniejszości jako pomocniczego przed organami powiatu. Zakwestionował on brak oszacowania skutków finansowych dla budżetów powiatów związanych z wprowadzeniem i używaniem na ich obszarze języka pomocniczego. Nowelizacja miała umożliwić organom nie tylko gminnym (jak dotychczas), ale także powiatowym używanie dwujęzycznych dokumentów oraz zwracanie się do organizacji mniejszości narodowych i etnicznych w Polsce z pismami dwujęzycznymi. Petenci należący do mniejszości mieliby prawo do zwracania się do organów gminy i powiatu w języku pomocniczym w formie pisemnej lub ustnej, w tym uzyskiwania odpowiedzi i zaświadczeń również $\mathrm{w}$ języku pomocniczym ${ }^{48}$.

Odnośnie do dodatkowych nazw miejscowości, na wniosek mniejszości rada gminy mogłaby również podjąć w formie uchwały decy-

${ }^{47} \mathrm{~W}$ obecnym stanie prawnym taka możliwość istnieje jedynie w postępowaniu przed organami gminy.

48 Prezydent zawetowat nowele ustawy o mniejszościach narodowych i etnicznych, http:// www.pap.pl/aktualnosci/news,423492, prezydent-zawetowal-nowele-ustawy-o-mniejszosciach-narodowych-i-etnicznych.html (dostęp: 20 stycznia 2016). 
zję o ustaleniu dodatkowej nazwy miejscowości lub obiektu w języku mniejszości. W przypadku odrzucenia wniosku o ustalenie dodatkowej nazwy istniałaby możliwość odwołania się od uchwały rady gminy. Do tej pory, gdy wniosek jest odrzucany bez podjęcia uchwały, nie istnieje możliwość odwołania się od decyzji rady gminy. Nowelizacja ustawy przewidywała również możliwość powołania pełnomocnika ds. mniejszości narodowych i etnicznych przez wójta, burmistrza, prezydenta miasta, starostę i marszałka województwa. Obecnie tylko marszałek województwa może powołać taką osobę ${ }^{49}$.

Prezydent zawetowaną nowelizację ustawy wraz z umotywowanym wnioskiem jego decyzji przekazał Sejmowi do ponownego rozpatrzenia. Sejm ma możliwość odrzucenia weta prezydenta większością trzech piątych głosów, w obecności co najmniej połowy ustawowej liczby posłów. A ponadto gdy do końca kadencji Sejm nie zajmie się prezydenckim wetem, to nowelizacja ustawy, tak jak projekty ustaw, będzie podlegać zasadzie dyskontynuacji ${ }^{50}$. Nowelizacji zapewne będzie potrzebna nowa inicjatywa ustawodawcza, jednak nie należy jej się spodziewać ze strony obecnego rządu.

Podsumowując, ustawa o mniejszościach narodowych i etnicznych oraz języku regionalnym, która usankcjonowała wprowadzenie podwójnego nazewnictwa na tablicach miejscowości i urzędów oraz języka pomocniczego w gminach, przede wszystkim na Górnym Śląsku (język niemiecki) i Kaszubach (język kaszubski), przyniosła pozytywne przemiany postaw społeczności polskiej wobec mniejszości. W świadomości społecznej ustawa upowszechniła przekonanie, że mniejszości narodowe i etniczne są trwałym elementem życia w Polsce. Mają swoją specyfikę i swoje prawa. Patrząc z perspektywy lat na sprawę wprowadzania podwójnych nazw miejscowości na Górnym Śląsku, zwłaszcza w jego opolskiej części, można stwierdzić, że dokonała się ewolucja ich społecznego postrzegania. Nie mówi się już o możliwościach naruszenia praw większości i suwerenności narodowej tego regionu, zaczęto natomiast zwracać uwagę na skomplikowane tradycje lokalne i zróżnicowane historycznie losy różnych grup społeczności żyją-

\footnotetext{
49 Ibidem.

50 Ibidem.
} 
cej na tym terenie. Tablice dwujęzyczne, które zwłaszcza na początku wywoływały oburzenie, dziś mogą świadczyć o ich akceptacji i traktowaniu jako części wspólnego krajobrazu. Stanowią one stały element szczególnie opolskiego pejzażu. Kiedyś stosunkowo często dochodziło do ich niszczenia, natomiast dziś zdarza się to już tylko sporadycznie. Tablice te coraz częściej nie budzą większych emocji. Rośnie akceptacja tablic dwujęzycznych i innych form obecności niemieckiej tożsamości w przestrzeni publicznej.

Należy także podkreślić, że nawet gdy w początkowym okresie wprowadzania podwójnego nazewnictwa były prowadzone nieraz pełne emocji dyskusje dotyczące podwójnego nazewnictwa, to nigdy nie prowadziły one do lokalnych konfliktów etnicznych. Dyskusje te stanowiły odbicie sporów o tożsamość regionu i zamieszkującej go ludności, a także jego tradycji historycznych. Dodatkowe nazwy miejscowości w języku niemieckim umieszczane na tablicach oraz możliwość stosowania języka niemieckiego jako języka pomocniczego w urzędach są dziś dowodem na wielokulturowość regionu. Stało się to codziennością. Większość i mniejszość nie funkcjonuje "osobno", lecz żyje ze sobą wspólnie mimo swej różnorodności kulturowej i językowej. Obecny sposób społecznej percepcji dwujęzyczności w przestrzeni publicznej prowadzi nie tylko do coraz większej społecznej otwartości i tolerancji, ale także do dobrej i spokojnej koegzystencji na jednym terenie - większości i mniejszości. Jedni i drudzy tworzą wspólnie w swoich miejscowościach społeczności wielokulturowe.

\section{Abstract \\ The Introduction of Double Names on Village and Office Signs and the Auxiliary Language in the Municipalities of Upper Silesia and their Public Perception}

The law on National and Ethnic Minorities and Regional Language of 2005 regulates not only matters related to the preservation and development of the cultural identity of national and ethnic minorities in Poland, but also the problem of bilingualism, auxiliary language and bilingual names. It allows minorities living in Poland to express and emphasize their presence, among other things, by placing names in the minority language on signs next to the official names of places and 
physiographic objects. Polish society was most concerned about the introduction of dual place names and the use of minority languages as auxiliary languages in offices in some municipalities in Poland, especially in Upper Silesia. Issues of cultural cultivation and the use of education aroused far fewer objections and did not cause doubts.

This article shows not only the origins and the role of the introduction of bilingual village and office signs and the German language as the auxiliary language in offices in Upper Silesian municipalities (in the provinces of Opole and Silesia), but also the perception of this phenomenon by both the German minority and the majority society. This paper also presents the legal and sociological aspects of the discussed issues. 